\title{
Investigating the effects of strategic positioning for development of modern banking services
}

\author{
Vahid Anvar Keivia ${ }^{a}$, Saba Kamali ${ }^{a}$, Ebrahim Shahrami Manesh ${ }^{b}$, Samira Najafi ${ }^{b}$, Ali Arfaeean ${ }^{a}$ and \\ Seyed Shahab Mousavi ${ }^{\mathbf{a}^{*}}$
}

${ }^{a}$ Department of Management, Tehran South Branch, Islamic Azad University, Tehran, Iran

${ }^{b}$ Department of Management, Tehran Central Branch, Islamic Azad University, Tehran, Iran

\section{CH R O N I C L E A B S T RAC T}

Article history:

Received December 28, 2013

Accepted 24 March 2014

Available online

March 282014

Keywords:

Banking industry

Strategic positioning

Quality positioning

Consumer positioning

\section{Introduction}

During the past few years, there have been tremendous changes on banking services and many bank customers are able to do their daily banking activities using recent advances of technology such as internet banking, telephone banking, etc. (Hoffmann et al., 2012). The competition in banking industry escalates and most banks try to introduce new services to attract more customers (Ries \& Trout, 1986; Kotler, 1998; Schellhase et al., 2000). They also try to reconsider their positioning strategies to improve their market share, increase their profitability, etc. There are literally various methods for competitive product positioning such as Nash equilibria. According to Marks and Albers (2001), the more aggressive product positioning behavior from attempts to reduce profit differences relative to competitors because profit asymmetry happens in many market settings, it is an essential factor to consider in making product positioning decisions in a competitive environment. Darling (2001) concentrated on the relative importance of successful competitive positioning in the European 
consumer market by proposing a model for building a competitive position in the minds of consumers. They described that their model could help marketing executives reach a better competition position in the European market by the successful implementation of components and elements identified. Gwin and Gwin (2003) proposed a brand positioning to develop a sustainable competitive advantage on product attributes in the consumer's mind. Akdag and Zineldin (2011) studied the competitive positioning of banks including state-owned, domestic and foreign banks operating in Istanbul, Turkey. They tried to check the competitive marketplace and to detect the major quality attributes, which bankers themselves and their customers applied in determining the overall perception of a given bank and services offered. They explained that customers of banks were not fully receiving what they wanted from their expectations. Hassan and Craft (2005) empirically investigated the relationship between positioning strategies and bases of segmentation in international markets. They recommended the combined implementation of both macro- and micro-bases of segmentation to leverage similar strategic positioning across global markets. da Silva Monteiro and Guzmán (2009) detected important factors of environmental strategic positioning adopted by Portuguese large firms.

\section{The proposed study}

This paper investigates the effects of seven strategic positioning factors of the success of modern banking system. The proposed study uses a questionnaire in Likert scale. The proposed study considers the following seven hypotheses (See Fig. 1),

1. Property positioning influences on development of advanced banking system, positively.

2. Advantage positioning influences on development of advanced banking system, positively.

3. Consumer positioning influences on development of advanced banking system, positively.

4. User positioning influences on development of advanced banking system, positively.

5. Competitive advantage positioning influences on development of advanced banking system, positively.

6. Quality positioning influences on development of advanced banking system, positively.

7. Merchandise category positioning influences on development of advanced banking system, positively.

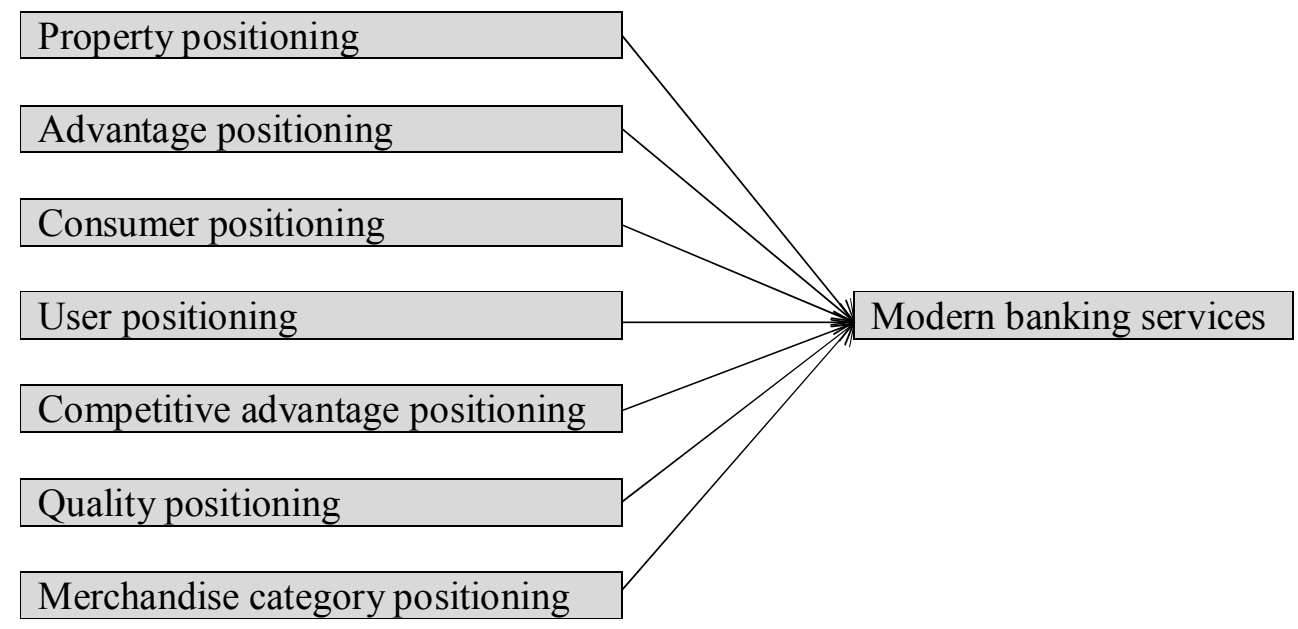

Fig. 1. The proposed study

The study has been implemented among some regular customers of an Iranian bank. The sample size is calculated as follows, 
$N=Z_{\alpha / 2}^{2} \frac{p \times q}{e^{2}}$,

where $N$ is the sample size, $p=1-q$ represents the probability, $z_{\alpha / 2}$ is CDF of normal distribution and finally $\varepsilon$ is the error term. For our study we assume $p=0.5, z_{\alpha / 2}=1.96$ and $e=0.05$, the number of sample size is calculated as $N=385$. We have distributed the questionnaires among some participants and Fig. 2 shows personal charactersitcs of the people who took part in this survey. Cronbach alphas for the questionnaire of the survey has been calculated as 0.763 . Fig. 2 shows details of the personal characteristics of the people who participated in our survey.

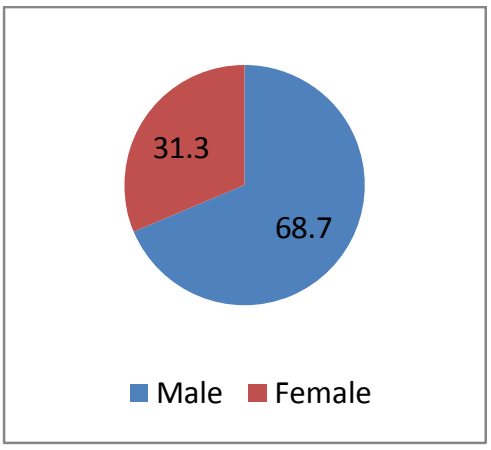

Gender

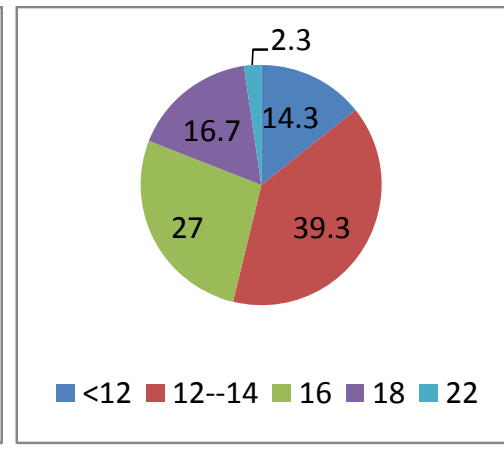

Years of education

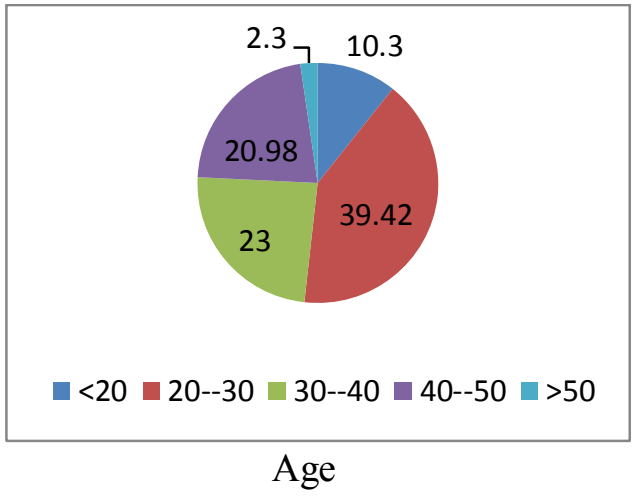

Age

Fig. 2. Personal characteristics of the participants

As we can observe from the results of Fig. 2, most participants were male, they had some university background. Besides, the survey indicates that most people who took part in our investigation were middle aged people. The implementation of Kolmogorov-Smirnove test has indicated the data were not normally distributed. Therefore, we apply Spearman correlation ratio as well as Stepwise regression test to verify the hypotheses of the survey.

\section{The results}

In this section, we give details of our results on testing four hypotheses of the survey. Table 1 shows details of the results of Spearman correlation ratio on testing the effects of seven positioning strategies on development of modern banking system.

\section{Table 1}

The results of testing the effect of positioning strategies on development of modern banking system based on Spearman correlation

\begin{tabular}{llccc}
\hline Hypothesis & Relationship & r & Sig. & Result \\
\hline First & Property positioning $\rightarrow$ Modern banking services & 0.389 & 0.005 & Confirmed \\
Second & Advantage positioning $\rightarrow$ Modern banking services & 0.443 & 0.002 & Confirmed \\
Third & Consumer positioning $\rightarrow$ Modern banking services & 0.302 & 0.004 & Confirmed \\
Fourth & User positioning $\rightarrow$ Modern banking services & 0.246 & 0.008 & Confirmed \\
Fifth & Competitive advantage positioning $\rightarrow$ Modern banking services & 0.195 & 0.02 & Confirmed \\
Sixth & Quality positioning $\rightarrow$ Modern banking services & 0.124 & 0.016 & Confirmed \\
Seventh & Merchandise category positioning $\rightarrow$ Modern banking services & 0.168 & 0.000 & Confirmed \\
\hline
\end{tabular}

The results of Table 1 indicate that there were positive and meaningful relationship between seven components of strategy positioning and modern banking development when the level of significance is five percent. The highest correlation is between Advantage positioning and development of modern banking services $(r=0.443$, Sig. $=0.002)$ followed by the relationship between Property positioning and development of modern banking services $(\mathrm{r}=0.389$, Sig. $=0.005)$, between Consumer positioning and development of modern banking services $(r=0.302, \mathrm{Sig} .=0.004)$. In addition, there were positive and meaningful relationships between User positioning and development of modern banking services $(\mathrm{r}=0.246$, Sig. $=0.008)$, between Competitive advantage positioning and 
development of modern banking services $(r=0.195$, Sig. $=0.02)$, between merchandise positioning and development of modern banking services $(\mathrm{r}=0.168$, Sig. $=0.000)$. We have also performed stepwise regression analysis and Table 2 shows the results of the survey.

\section{Table 2}

The summary of stepwise regression analysis

\begin{tabular}{lccccc}
\hline Variable & Coefficient & Standard error & Standard coefficient & t-value & P-value \\
\hline Intercept & 58.756 & 5.382 & & 13.682 & .000 \\
Property positioning & .562 & .318 & .402 & 2.533 & .003 \\
User positioning & .543 & .286 & .368 & 2.821 & .000 \\
Competitive advantage & .507 & .215 & .335 & 2.250 & .017 \\
\hline
\end{tabular}

As we can observe from the results of Table 2, three strategy positioning components including property positioning, user positioning and competitive advantage influence positively on development of modern banking services $(\alpha=0.05)$.

\section{Conclusion}

In this paper, we have presented an investigation to learn more about the effects of various strategy positioning on development of modern banking services in Iran. The study has distributed a questionnaire among some randomly selected people and using Spearman correlation ratios as well as stepwise regression analysis, the study has determined that three strategy positioning figures including Property positioning, User positioning and Competitive advantage influence positively on development of banking services $(\alpha=0.05)$.

\section{Acknowledgement}

The authors would like to thank the anonymous referees for their comments on earlier version of this paper.

\section{References}

Akdag, H. C., \& Zineldin, M. (2011). Strategic positioning and quality determinants in banking service. The TQM Journal, 23(4), 446-457.

Darling, J. R. (2001). Successful competitive positioning: the key for entry into the European consumer market. European Business Review, 13(4), 209-221.

Gwin, C. F., \& Gwin, C. R. (2003). Product attributes model: a tool for evaluating brand positioning. Journal of Marketing Theory and Practice, 11(2), 30-42.

Hassan, S. S., \& Craft, S. H. (2005). Linking global market segmentation decisions with strategic positioning options. Journal of Consumer Marketing, 22(2), 81-89.

Hoffmann, A. O., Franken, H., \& Broekhuizen, T. L. (2012). Customer intention to adopt a fee-based advisory model: An empirical study in retail banking. International Journal of Bank Marketing, 30(2), 102-127.

Kotler, P. (1998). Marketing management and strategy. Prentice - Hall international. Inc. Englewood cliffs. New Jersey.

Marks, U.G., \& Albers, S. (2001). Experiments in competitive product positioning: Actual behavior compared to Nash solutions. Schmalenbach Business Review, 53, 150-174.

Ries, A., \& Trout, J. (1986). Positioning: The battle for your mind (pp. 34-71). W. Sabin, \& M. Hamerling (Eds.). New York: McGraw-Hill.

Schellhase, R., Hardock, P., \& Ohlwein, M. (2000). Customer satisfaction in business-to-business marketing: the case of retail organizations and their suppliers. Journal of Business \& Industrial Marketing, 15(2/3), 106-121.

da Silva Monteiro, S. M., \& Guzmán, B. A. (2009). Determining factors of environmental strategic positioning adopted by Portuguese large companies. Social Responsibility Journal, 5(4), 478-498. 